til sig selv og sine medmennesker er blevet tingsliggjort, fremfører Ratzinger, at mennesket i sig selv er ved at udvikle sig til en ting. Genteknologien er blot ét eksempel på, at fornuften er gået amok. Derfor har den brug for en instans, der kan begrænse og korrigere den, og denne instans er ifølge Ratzinger religionen.

Habermas og Ratzinger er således enige om, at fornuft og religion gensidigt kan korrigere hinanden og bør indgå i et dialogisk forhold. Og de er også enige om, at etableringen af en kosmopolitisk ret, som allerede Kant efterspurgte, er et must, hvis den multikulturelle verden skal kunne hænge sammen. Men derudover stiller Ratzinger et spørgsmål, som ikke har nogen plads inden for Habermas' diskursetik, der som bekendt fokuserer på, hvordan normer kan legitimeres rationelt og ikke hvilke normer, der bør legitimeres, nemlig spørgsmålet om forholdet mellem positiv ret og naturret. Den menneskelige væren er i sig selv bærer af værdier og normer, som det ikke står til os at opfinde, men som det er os pålagt at leve op til, og som må fastholdes på tværs af de positive retssystemer - islamiske, kristne, hinduistiske og demokratiske - hvis vi skal gøre os forhåbninger om fredelig sameksistens.

Så alt $i$ alt er der tale om en anbefalelsesværdig bog, der synes at blive stadig mere aktuel i takt med at konfrontationen mellem religiøse og sekulære samfund spidser til.

Rasmus Navntoft

\section{Kom nu!}

Samtaler med tidsainden og oprab imod den - Fra Ejvind Larsens 50 år på Information, redaktion ved Rune Lykkeberg, Informations Forlag 2005, 231 sider, kr. 248 ,-

Bogen Samtaler med tidsainden og opräb imod den er først og fremmest en velkomponeret hyldest til mennesket Ejvind 'Mangeord' Larsen, der igennem en menneskealder har virket som ildsjæl og åndelig indpisker ved Dagbladet Information. Som opmærksom politisk analytiker, som kritisk åndsarbejder, og som visionær folkelig vækkelsesprædikant. Til mennesket Larsen, der storrygende og jamrende sig over tidens elendighed - 'Verden er af lave!'-, alligevel ikke kan lade være med at stå op bare en gang til og råbe op med og mest imod tidsånden. Hvileløs i sin jagt på tidens falske ideologier og vanetænkning, og i sin gentagne opfordring til den danske folkelighed om at vågne op og gøre sig fri af dens egen selvforskyldte umyndighed: Kom nu!

Men bogen er meget mere end det. Den er også et lille stykke Danmarkshistorie, efterkrigstidens Danmark set inde fra en avis, Dagbladet Information. Et blik på den store historie set fra den flere gange lukningstruede avis' intime redaktionslokaler og fra Larsens hule på Esplanaden i København. Men den er også et stykke kulturhistorie, idet man her stifter bekendtskab med forfatterpersonligheder som Bjørn Poulsen og Villy 
Sørensen, teologerne Grundtvig, Kierkegaard og Løgstrup, filosoffen Marx, bevægelsen Heretica og tidsskriftet Vindrosen, politikerne Viggo Kampmann, Poul Nyrup Rasmussen og mange flere.

Alt sammen set gennem Ejvind Larsens briller, ledere, kronikker, klummer, analyser og reportager igennem de seneste 50 år. Siden dengang hvor han, som 19-årig troppede op på Information og spurgte, om han kunne blive journalist. Og hvis ikke, ja så ville han begynde at studere $i$ stedet. Det sidste var, ifølge Rune Lykkebergs glimrende forord til bogen, ikke særligt attraktivt for den vordende journalist og samfundsrevser. Opdraget som han var med Grundtvigs forbeholdenhed over for det akademiske, mente han, at man måtte 'udrette noget', og lige som svenskeren Strindberg mente han så, at journalistikken (mest) unddrog sig kritikken af det døde bogstav.

Bogen er inddelt i 4 hovedafsnit, der hver bærer bogstavet 'O' som signatur: 'Oplysning', 'Oprør', 'Opstand', 'Opgivelse'. De 4 betegnelser signalerer dels Larsens egen biografi fra at være oplysningsivrig venstreintellektuel i 60'erne, over hans indsats som profet for ungdomsoprøret og politisk aktivist i 70'erne og hans kamp for at få danskerne til at forstå det Økonomiske Demokratis velsignelser i 80'erne, og til hans næsten opgivende gestus i 90'erne i forhold til de politiske visioner om en økologisk bæredygtig planet, hvor få har for meget og færre for lidt. Fælles for alle bestræbelserne er, som Rune Lykkeberg fremhæver det, spørgsmålet: 'Hvordan får man folk til at bevæge sig'? Og svaret er: Ikke mindst gennem et aktivt engagement $i$ den offentlige dialog, der skal bygge bro mellem politik og kulturliv, imellem folket og magten, og som dermed samtidig skal gøre denne dialog mere demokratisk.

Men som sagt afspejler inddelingen og de udvalgte artikler, der lægger vægten på Ejvind Larsens journalistiske kamp, ikke kun Larsens biografi, idet den også er et stykke avis- og danmarkshistorie i miniformat. Det er også historien om Dagbladet Information, der går fra at være en borgerlig avis til at være et kritisk organ for centrale kræfter på venstrefløjen, ikke mindst anført af Ejvind Larsen selv, der skam ikke lader sig stoppe af trusler om fyring fra chefredaktøren. Og det er historien om Danmark i efterkrigstiden, med 50'ernes eksistentialisme og opgør med de gamle ideologier, 60'ernes velstand med fuld beskæftigelse, ungdomsoprøret og krisestemningen i 70'erne, den borgerlige (tilbage)vending i 80'erne og halvfemsernes pluralisme og orienteringsløshed efter ideologiernes og murens fald.

Larsens vision for en socialisme med et menneskeligt ansigt består fra begyndelsen af hans virke $i$ tilliden til dette 'Kom nu!', idet den socialistiske vision for ham ikke er paradis, men derimod slangen i paradis: At det var 
muligt at få tidsånden over på sin side ved at tale den ret imod, imod den autoritære skolepædagogik f.eks., at vække den danske folkelighed fra dens slummer, at forene det åndelige med det nyttige, kultur med politik, at transformere det snævre og tillige snæversynede krav om økonomisk velstand til et universelt ønske om menneskelig velfærd, bredt forstået. I tresserne og halvfjerdserne så det oven i købet ud til, at projektet skulle lykkes. Der gøres oprør mod professorvældet på universiteterne, og Larsen er også med i de initiativer, der fører til dannelsen af Statens Kunstfond $\mathrm{mm}$.

Men denne centrale placering i kulturlivet peger, lige som både Ejvind Larsens egne artikler igennem en menneskealder og selve bogen om og med ham, samtidig på det paradoksale eller uforløste i hele forehavendet: Målet var jo, at folket selv skulle tage magten, frigøre sig fra deres afmagt, skaffe sig af med autoriteterne og kunne selv. Larsens stædige 'Kom nu!' er $\mathrm{i}$ den forstand den intellektuelles forsøg på at gøre sig selv overflødig, kunne man sige. Det burde ikke være nødvendigt sådan at råbe op, men det er det desværre (stadig). Larsen bliver en slags tragisk helt, der nok virker for folket, men som ikke kan få sit dybeste ønske opfyldt: At være en mand af folket i stedet for en autoritet, som man kan dyrke, se op til etc. Den, der taler, har måske ikke magt, som han har agt, men han forsøger alligevel at opnå magt over sjælene.
Larsen er selv den første til at erkende sit eget nederlag, og heri består ikke mindst hans 'storhed': De store bedrifter udeblev, trods alt, det blev ikke rigtig til noget med det ØD (Økonomisk Demokrati), som han var en varm fortaler for (andet end lige internt på Information), lige som ungdomsoprøret hyppigt endte i selvfedme og arrogance. Svaret på hans spørgsmål: 'Er danske studenter for sløve til at gøre oprør mod systemet'? blev i sidste ende, at jo det var de skam, i hvert fald når engagementet $i$ længden gik ud over egne interesser. Efterfølgende bekendelser af eget 'synderegister', måske ikke fra Ejvind Larsen, men så fra en lang række andre fra dengang, har ikke forbedret indtrykket af en generation, som, med Larsens egne ord, alligevel var mere interesseret $i$ at have det godt end at gøre det godt. Larsen var også hurtigt ude med visioner om økologisk bæredygtighed, dengang tilbage $\mathrm{i}$ halvfjerdserne, men virker i dag desto mindre optimistisk på klodens fremtids vegne.

Alligevel bliver han ved, ildsjælen og samfundsrevseren. Han forsøger således - men med hvilket held? - at undgå at falde i den fælde, som kendetegner megen moderne kriseteori og mange klassiske dommedagsprofetier, og som består i, at kritikken hiver gulvtæppet væk under sig selv. Kritikken, mistankens hermeneutik, bliver altomfattende og der bliver ikke sten eller fundament tilbage, hvorfra kritikken kan tale eller som 
et nyt og bedre samfund kan bygges af og på. Universaliteten, utopierne, drømmene om en bedre verden og om at forene kultur med politik, lader sig imidlertid, og trods alt, ikke kvæle helt. Selv ikke midt i en globalisering, der mere og mere ligner en darwinistisk overlevelseskamp og en blind dyrkelse af den økonomiske vækstideologi med formentlig kommende naturkatastrofer til følge. Og selv ikke $i$ et samfund som det danske, der mere og mere lukker sig om sig selv og giver sig præster af forskellig religiøs observans i vold. Man kan også mene, at Larsens og daværende LOformand Thomas Nielsens tilslutning til tanken om Økonomisk Demokrati, igen før eller siden må blive højaktuelt stof, idet den da må gentænkes på et globalt niveau.

Summa summarum: Måske vil det vise sig, at mennesket alligevel ikke er det virkelige skadedyr på planeten, sådan som meget ellers kunne tyde på. Men det forudsætter utvivlsomt, at ikke blot Ejvind Larsen selv, men også undertegnede (suk!), ja at vi alle sammen, i sidste ende formår at efterleve hans insisterende 'Kom nu!'. Jens Viggo Nielsen

\section{God men ujaun Slok-antologi}

Paw Hedegaard Amdisen, Lars Gorzelak. Pedersen og Morten Riis (red.): Et menneske lades ikke i ro. Aarbus Universitetsforlag, 2006, 183 sider, kr. 198,-
Litteraturen omkring Johannes Sløk, der jo var professor i idéhistorie 1967-1977, er nærmest forbløffende lille, på trods af - eller måske netop på grund af - det enorme omfang af hans egen produktion. Det har de tre redaktører, Paw Hedegaard Amdisen, Lars Gorzelak Pedersen og Morten Riis, der alle er tidligere studerende ved idéhistorie, sat sig for at gøre noget ved med antologien Et menneske lades ikke i ro. Og til en vis grad virker det også overbevisende. Man må jo sige, at blot i og med at denne antologi er blevet udgivet, har man øget bestanden af Sløk-bøger betragteligt - der er vist nok kun to andre, Jan Lindharts Modernismens teolog og Hans Jørgen Thomsens Slok. Men til gengæld er det en meget ujævn antologi, der med fordel kunne have brugt en strammere redigering. Bidragene trækker i meget forskellige retninger.

Hans-Jørgen Schanz leverer til introduktion en række personlige anekdoter om Sløk. Ganske fornuftigt af to grunde. Sløk genererede ved sin personlighed en lang række anekdoter, som er af umiddelbar underholdende interesse og fint kan bruges som appetitvækker. Men Sløk-anekdoter har tillige ofte den effekt, at de belyser mandens tankegang. Schanz siger selv, at han aldrig kom til at kende Sløk rigtigt, og det afspejles også $\mathrm{i}$ anekdoterne, der mest af alt viser Sløks offentlige facade, udover den nærmest rørende historie om middagen som Schanz bliver inviteret til hjemme hos Sløk. Vil man have 